International Journal of Advanced Educational Research

ISSN: 2455-6157

Impact Factor: RJIF 5.12

www.educationjournal.org

Volume 3; Issue 1; January 2018; Page No. 124-128

\title{
Teaching discourse for indonesian language to basic students school: A conceptual review
}

\author{
Hasnah Matondang \\ University of Muslim Nusantara Al-Wasliyah, Indonesia
}

\begin{abstract}
This article aims to explain how to make the efective way the discourse in indonesian language. And how to explain about explository text for students in school, due to the fact that many students' errors are still found in the use of discourse in Indonesian language teaching especially for basic students schools. The data used in this monologue are cohesion, coherence grammartical cohesion, There are some text in indonesian language. The analysis was done by describing the text in a manalogue. The uses of discourse are described in a text. And use of discourse terms may depend on the status person, phenomenon, social status, etc. This decription is expected to be reference when we use the monologue in in Indonesian language teaching. To achieve the maximum teaching Indonesian language, one that can be taken is to teach the intensive use of discourse terms in Indonesian sentences by using the classification about cohesion. There are pronoun, Substitution, Ellipsis, Conjunction and lexical. Educating the student with discourse in schools, and will create students their attitudes to behave in the learning activity.
\end{abstract}

Keywords: indonesian language teaching, monologue discourse. basic students schools

\section{Introduction}

Indonesian language teaching in fact, includes four types of skills such as listening, speaking, reading, and writing. These skills became the focus of Indonesian language teaching right now. Language in communication is meaningful when it is well arranged and relevant with context surrounding the communication or social functions (Riyadi Santoso, 2007:15) [12]. For example interview on the TV showed that the language include the former of ideology and to progress the socio-cultural. Generally, the language is called with respect to matters outside of the discourse and diveded into oral language and written language (Sumarlam, 2006:1) ${ }^{[15]}$. The level of nonliterary covers the suitability of a situation where, when, and to whom the idea conveyed. According to Jufri (2006: 1) ${ }^{[6]}$, language always used integrated the sound or communication event that occurs in every human activity has a variety of elements.

Discourse' is introduced by linguists in Indonesia especially of Monologue discourse. Or defines discourse as 'the most complete set of language, the grammatical hierarchy is the highest or greatest grammatical unit'. This discourse is realized in the form of the whole essay (novels, books, encyclopedia series, and so on), paragraphs, sentences, or words that carry complete message.

A text is the unit of language. It is not grammatical unit, like clause or sentence and not defined by the size. Text used to refer to any passage, spoken or written whatever length that does form a unified whole, Halliday and Hasan (2006:4-6). It means that maybe the text spoken or written, prose / verse, dialogue or monologue. It maybe anything from a single proverb to a whole play. a text is sometimes envisaged to be some kind of super-sentence, a grammatical unit that is larger than sentence is related to a clause, a clause to group and so on. Sumarlam (2006:35) ${ }^{[15]}$. Starting from the opinion of
Sumarlam (2006:35) ${ }^{[15]}$, describes the Lexical cohesion is about meaning in the text. It concerns the way in the systematics.

The competence of writing is related about the curriculaum in 2013 of Indonesia goverment "the creative process because it is a process of reaching out for one's thought and discovering them". The students must be active and focus about Exposition, and the students can be composed as the modes of discourse, along with imaginative, and found that some difficult to do it, because they had problem about blackground status.. This paper will explain conceptual steps on teaching discourse. There are three research questions that will be answered in this paper. Those questions are:

1. What are the strategies to analyzing the Monologue discourse?

2. How to plan teaching the Monologue discourse?

This article will give some consideration how to teach Monologue discourse especially for basic school. The focus is on Indonesian language materials in the classroom.

\section{Theoretical Review}

Indonesian language teaching aims at understanding and uses language in Indonesian both in terms of form and meaning based on need. Therefore, to find out more about language learning pattern of Indonesia, there are some patterns used in the process of teaching discourse. Discourse is communicative event which language plays as a prominent role. It requires a sender (writer, speaker), a receiver (reader, listener), and a message that is being communicated. Etymologically, the discourse comes from the Sanskrit, which wac / wak / profession that is to say and speak (Douglas dalam Mulyana, 2005: 3). According to Tarigan, (1987:29) Good and complete discourse characteristics are discourse having cohesion 
Grammatical relationship between parts of a sentence essential for its interpretation.

Language in communication is meaningful when it is well arranged and relevant with context surrounding the communication. The arrangement and relevance of language is discourse. The term discourse itself is very ambiguous. At first opinion, discourse focuses on analysis of verbal structures and cognitive process and another opinion claims that discourse focuses on interaction in society. (Sudarianto, 2007: 41) The discourse is as a communication of thoughts through words, expression of ideas, or idea of conversation. In terms of shape, the discourse can be a complete language and has a grammatical unit that can be paragraphs, sentences, or words that carry a full mandate. The the main target behavior is woven and coupled into an event that happened in one unit of time, such as novel, book, ensiklopedia series, paragraph, and etc. (Kridalaksana, 2008: 259)

According to Sumarlam (2006: 15) said that the internal elements associated with the formal aspects of language, such as speeches, lectures, sermons, and dialogues, or in writing area such as short stories, novels, books, letters, and written documents, There are two terms that are very fundamental in discourse analysis which studies the relation among a text within the other texts. The terms are cohesion and coherence. Starting from the opinion of Tarigan (2007: 27) ${ }^{[7]}$ It observes whether a text makes sense or not. Text that makes sense should have unity with context surrounding it. The context can be other discourses (text), intention with the writer or speaker, setting, time, place, and other aspects of communicative context.

Discourse analysis is the study of the linguistic for this section or the discourse relations between sentences that are suprasentence (Kartomiharjo, 2007: 12). Discourse analysis was born from the realization that the issues contained in this communication. It is not limited to the use of sentences or parts of sentences, speech function, but also covers the structure of the message. (Keraf, G 2005: 48) ${ }^{[8]}$. In indonesian, discourse analysis is developed in the middle 1980 especially for antropology, sociology and politic (Oetomo, 2006: 4) ${ }^{[11]}$.

Samsuri said that the related about discourse, they were (a) discourse context (b) topic, theme, and tittle of discourse (c) cohesion and discourse coherence (d) reference and discourse inference. Discourse context is to helped the contribution about the meaning of speech or we called that discourse situation. This situation might be explicit in discourse but can be advanced with the elements of (discourse) or the characteristic of (discourse) or coordinates of (discourse) such as: speaker, listerner, time, place or location, topic, forms of messages, events, channels and codes (Samsuri dalam Arifin, (2008: 13) ${ }^{[3]}$. With drawn the aspects we are divided into two approach and can be analyzed into two directions, namely text itself with the microstructural approach and from outside of the text or from the context to the macrostructural approach. Cohesion constitutes a language formal aspect in a discourse. This means that cohesion is a 'syntactic organization' (Chaer, 2008: 4) ${ }^{[4]}$. Thus, This syntactic organization is a coherently and solidly integrated sentence structure.

\section{The Cohesion}

Cohesion is such a possibility device existing in a language that can make certain 'text' has a unity. From that sense, Chaer (2008: 1) ${ }^{[4]}$ explains the meaning of correlation, either lexical or grammatical meaning, shall be necessary to be integrally implemented in the unity of text. Hence a discourse must have two essential elements they are cohesion and coherence. Discussion discourse on the other side is discussing language and speech must considering the situation. Here, the meaning of a language is the sequence contexts and situations. Its means that the discourse discussion is basically a discussion of the relationship between contexts contained in the text. The aims to explain the relationship between sentences or between utterances that make up the discourse. Based on theoretical conceptual level, the discourse is defined as a public domain of all statements, that all speech or text that has meaning and have an effect in the real world, while, in the context of its use, discourse means a set of statements that can be grouped into certain conceptual categories.

Talking about writing is related about a unit of language in use, not grammatical unit, like a clause or a sentence; and it is not defined by its size. Then, a text is the best regarded as a semantic unit, that is a unit nor of form but of meaning. Thus, it is related to a clause or sentence not by size but by realization. Moreover, a text does not consist of sentences, but it is realized by sentences, and a set of related sentences is the embodiment or realization of a text. The cohesion can be divided into five kinds of forms; Halliday in (Tarigan, 2006: 93) [17] "such as pronouns, substitution, ellipsis, and conjunction, Lexical.

\section{a. pronouns (Kata Ganti)}

Pronouns is defined as a word or phrase that may be substituted for a noun or noun phrase, which once replaced, is known as the pronoun's antecedent. Examples include:saya, kami, kamu, dia, mereka (I, we, you, she, he, they), pronouns of pointer: ini, itu, disini, disana (this, that, here, there), possessive pronoun (mine, yours, (singular), yours (plural), ours, hers, his).Interrogative pronouns: apa, siapa, dimana (what, who, where), Relative Pronouns: yang (who, whom, what, which, that, dan whose.), and finally, Indefinite Pronouns seseorang, sesuatu, siapapun, ара saja, sетиa orang, semuanya, tak seorang pun, tidak ada (someone/somebody something, anyone, anybody/anything, everyone/everybody, everything, no one/nobody, nothing).

\section{b. substitution,}

Substitution is the process or the result about the replacement of elements language by accrossing to other elements in a larger unit and obtain distinguishing it or to describe the specific of structure (Kridalaksana, 984: 185). Substitution is a grammatical relationship, it is the relationship of words and mean. In Indonesian language may be nominal, verbal, clause, or a mixture; for example one, just like that, that way, so.

For example the text in the bellow it

Saya dan paman pergi ke warung kopi. Paman memesan es teh manis. Saya juga mau satu. Keinginan kami rupanya sama. 
Selain itu, paman bercita-cita menyekolahkan anak-anaknya ke perguruan tinggi agar mereka menjadi sarjana. Saya rasa cita-cita yang demikian merupakan cita-cita semua orang tua. Karena ayah dan ibu pun melakukan hal yang sama demi masa depan anak-anaknya.

My uncle went to the coffee shop. Uncle ordered sweet iced tea. I also want one. Our desire apparently the same. Additionally, uncle aspire to send their children to college so their degree. I think the ideals of such a aspirations of all parents. Because the father and mother would do things The same for the future of their children.

\section{c. Ellipsis}

Ellipsis is elimination process of word or another language element (Kridalaksana, 1984: 45). state " ellipsis is simply „substitusion zero". There are three types of ellipsis: nominal, verbal and clausal. We can seen the text in the bellow it

Andi dan Doni senang sekali mendaki gunung sebagai sport utama mereka. Justru Rado dan Rezky sebaliknya; mereka senang memancing. Setiap hari Minggu mereka pergi memancing di Situ Lembang. Apakah Anda pernah juga memancing ke Situ Lembang pada hari Minggu atau pada hari-hari libur lainnya? Belum, bukan? Aduh, sayang sekali! Coba sekali-sekali. Pasti menyenangkan.

Andi and Doni are very happy to climb the mountain for majoring the sports but Rado and Rezky precisely the opposite; they are happy fishing. Every Sunday they go to fishing in Situ Lembang. Have you ever been fishing to Situ Lembang on Sundays or other holidays? Yet, is not it? Alas, alas! Try again. Definitely fun.

\section{d. Conjunction}

Conjunction is a form or language unit which its function as connector (Anggono (2006), Conjunction is one type of grammatical cohesion that is done by connecting one element to another element in the discourse. Elements that can be bundled units lingual words, phrases, clauses, sentences, and can also be a greater element of it.

- Adversative conjunctions : tetapi, namun (but, however)

- Conjunction clauses : sebab, karena (Because)

- Coordinative conjunctions : dan, atau, tetapi (and, or, but)

- Correlative conjunctions : entah/enyah, baik/maupun (either, go away, either or)

- Subordinating conjunctions : meskipun, kalau, bahwa (although, if, that)

- Conjunction temporal : sebelum, sesudah (before, after)

\section{e. Lexical}

Lexical. Lexical cohesion appearing in discourse just means some semantic relationship between partial terms, including reproducibility and co-occurrence. Reproducibility relationship of the vocabulary refer to a particular word in the original word, synonyms, approximate meaning word, antonyms, hyponyms, general word and other forms reappear in the discourse. Sentences in a discourse link each other by this relationship of reproducibility. Co-occurrence relationship of words means the tendency of the common occurrence.

a. Repetitions (reps): pemuda-pemuda (youths)

b. Synonym: pahlawan-pejuang (Hero-warrior)

c. Antonym: putra-putri (sons and daughters) d. hyponymy and hypernymy: angkutan darat-kereta api, bis (Land freight-train, bus)

e. Collocation: buku, koran, majalah-mediamassa (Books, newspapers, magazines, mass media)

f. equivalence: belajar, mengajar, pelajar, pengajar, pengajaran (Learning, teaching, students, teachers, teaching)

\section{The Coherence}

Coherence basically means intelligibility and/or consistency. In that sense, a speech and/or a piece of writing is coherent and, therefore, it has coherence, if it is intelligible and consistent. If it is not intelligibleand not consistent, the speech and/or writing is not coherent. to rely on cohesion relationships. Cook in (Arifin and Rani, 2000: 73) states that the use of the tool of cohesion is essential to form a complete discourse, but it is not enough to just use the marker of the katon. There are other factors that influence, such as the relevance and external textual factors (extratextual factors) that contribute to determining the integrity of the discourse. Conformity between the text and the real world can help create a condition for forming a complete discourse. Other factors such as cultural knowledge also help in creating text become coherence.

According to Chaer (2006:118) It can express as the language spoken discourses that are classified as interactive dialogue or discourse PolyLog. In terms of exposure of discourse expressed in six types of narrative discourse is a form of discourse that is the main target behavior is woven and coupled into an event that happened in one unit of time, such as short stories, novels, romance, poetry, films, and case- it is directly related to historical events. Procedural discourse is a discourse in the form of a series of utterances that contain the explanation of the existence of something. Hortatory discourse is a discourse that is more about flavor than the ratio of the judgment contains an invitation, advice, or encouragement that can evoke a sense of heroic to perform an action. Expository discourse is discourse that exposes that can expand the view or knowledge of listeners and readers. Descriptive discourse is a discourse that contains a series of utterances on the object or objects or events based on the actual situation so that listeners and readers will see it as a direct or apparent in the speech.

\section{The Grammartical cohesion}

The grammatical cohesion includes reference, substitution, ellipsis, and conjunction. Meanwhile, lexical cohesion includes repetition and collocation. Both of them are established with two different elements. Grammatical cohesion is established with the use of grammatical elements of the text expressing the semantic relation within and between the sentences. It includes reference, substitution, ellipsis, and conjunction.

According to Halliday dan Hasan (dalam Rosidi, 2006:117) ${ }^{[6]}$ classify cohesion into grammatical and lexical cohesion. The grammatical cohesion includes reference, substitution, ellipsis, and conjunction. Meanwhile, lexical cohesion includes repetition and collocation. Both of them are established with two different elements. Grammatical cohesion is established with the use of grammatical elements of the text expressing 
the semantic relation within and between the sentences. It includes reference, substitution, ellipsis, and conjunction. reference), As a general rule therefore, reference items may be eksophoric or endophoric; and if, endophoric may be anaphoric and cataphoric. This scheme will allow us recognize certain distinction within the class of reference items, according to their different uses and "phoric"tendencies.d Tools (Rosidi, 2006:97).

\section{Results}

It is widely believed that language has four skill, Listerning, Speaking, Reading, and Writing. From those skill, Teaching writing skill is aimed to students can be pouring ideas, thought, opinions, or experience in writing. In addition, it takes all the intricate use of language norms including the enhanced spelling appropriately and the selection of language diversity that suits the context of communication. In here, this is real situation as the compliment of designed language which is set up by the teachers.

The first steps in analyzing the discourse the linguistics. Those items that should be are the use of Pronoun, Substitution, Ellipsis, Conjunction and lexical. The next one is sociolinguistic, the teacher asked students to analyzed the literary works based on social rules and norms especially for basic students scholls. After analyzing social norms and rules, teachers and students need to analyzes the strategies that is used by author to send and respon ideas in the written and spoken form. It could be use through analyzing the main idea, supporting idea, explanition, and moral value. The next activities is analyzing the expository discourse by students, because it is realted about discourse competences for example: to make monologue for students and compose the expository text, students will find discourse and strategies to explain the message as the procedure of curricullum in 2013

Finally this paper noticed about for basic students schools students' grammar in writing is basically correct, sentences are also reasonable and smooth, and the structure of article is disorder, poor works, lack of logic with the statement and paragraphs, the lack of discourse coherence. In writing teaching, therefore, do not think highly of the learning and use of discourse cohesion theory, and improve students' ability in discourse construction, it is difficult to train out a high level of writing skills. To do this, first we should realize the importance of textual study, and teach theory of the discourse cohesion systematically, and applied to the student the teaching of writing. Make students attach importance to the overall structure of the article and the analysis of the ideological content, making clear to the clue of text development, realize, the entire train of thought, comprehend the specific role of cohesion in discourse construction. Also, enlarge students' vocabulary, guide students to use a variety of terms, such as: the original words, synonyms and approximate meaning words, hyponyms and summary words etc, all kinds of ways in lexical cohesion to express, to improve language dull phenomenon. Teachers should systematically, in a planned way to do more training of writing coherence knowledge. Just as; design filling blanks, make sentences, interference into paper and other special exercises, imitation of creative writing, such as rewriting, repeat, copy writing, paying special attention to composition of overall planning and the use of cohesive devices.

The indicators examined in the teaching of writing skills that are compiled by simple observation report, develop a framework by being an essay, compose a letter, write a summary of the text, compile one of the literary works, and craft dialogue of experience.

\section{Conclusions}

To sum up, the theory of discourse cohesion and analysis is an important means of textual research. In the teaching, rationally use the theory of discourse cohesion and analysis, you can better help students grasp the chapter structure of the article in general, improve the level of the students' reading, writing. This way of teaching for teachers also put forward the corresponding requirements. Teachers must have a comprehensive and thorough understanding of this theory and consciousness of discourse analysis. And we should be good at exploring the teaching method in teaching and applied to the practice. Continuously explore and improve them, then you can comprehensively improve the student's application ability of indonesian language esppecially for basic school.

\section{References}

1. Alwi, Hasan dkk. Telaah Bahasa dan Sastra. Jakarta: Yayasan Obor Indonesia, 2006.

2. Anggono, Priyo. Analisis Kohesi Antarkalimat Kolom Tajuk Rencana, 2006.

3. Arifin, Bustanul. Prinsip-prinsip Analisis Wacana. Jakarta: Depatemen Pendidikan Nasional, 2008.

4. Chaer, Abdul. Pengantar Semantik Bahasa Indonesia. Jakarta: Rineka Cipta, 2008.

5. Halliday MAK. dan Ruqaiya Hasan. Cohession In English. New York. Longman Group Limited, 2006.

6. Jufri. Strukur Wacana dalam Lontara La Galigo: Kajian Kritis. Disertasi. (Tidak diterbitkan). Malang: Jurusan Pendidikan Bahasa Indonesia. Program, 2006.

7. Kartomihardjo, Soeseno. Analisis Wacana dengan Penerapannya pada Beberapa Wacana, dalam Bambang Kaswanti Purwo (ed). PELLBA 6. Yogyakarta: Kanisius, 2007.

8. Keraf G. Komposisi II. Ende Flores: Nusa Indah. Kumala, R. 2015. Analisis Aspek Leksikal dan Gramatikal Pada Teks Narasi Siswa Kelas VII SMP Negeri, 2005, 2.

9. Kridalaksana, Harimurti. Kamus Linguistik. Jakarta: P.T. Gramedia Pustaka Utama, 2005.

10. Mulyana. Kajian Wacana: Teori, Metode, \& Aplikasi Prinsip-prinsip Analisis Wacana. Yogyakarta: Tiara Wacana, 2005.

11. Oetomo, Dede. Pelahiran dan Perkembangan Analisis Wacana, 2006.

12. Riyadi Santoso. Semiotika Sosial: Pandangan terhadap Bahasa. Surabaya: Pustaka Eureka, 2007.

13. Rosidi, Sakban. Analisis Wacana Kritis sebagai Ragam Paradigma Kajian Wacana. Makalah disajikan pada Sekolah Bahasa, atas prakarsa Himpunan, 2007.

14. Sudaryanto. Metode dan Aneka Teknik Analisis Bahasa. Yogyakarta: Duta Wacana University Press, 2007. 
15. Sumarlam (ed). Teori dan Praktik Analisis Wacana. Surakarta: Pustaka Cakra, 2006.

16. Sumarlam (ed). Analisis Wacana. Surakarta: UNS Press, 2005.

17. Tarigan HG. Pengajaran Wacana. Bandung: Penerbit Angkasa thejakartapost.com diakses tanggal, 2006-2008.

18. Tarigan, Henry Guntur. Pengajaran Wacana. Bandung: Angkasa, 2007. 